\title{
Pā Harakeke as a research model of practice
}

\author{
Ange (Andrea) Watson (Te Āti Awa, Ngāti Mutunga, Taranaki), Massey University, \\ Aotearoa New Zealand
}

\begin{abstract}
INTRODUCTION: This article will present a research study with seven Māori social workers (kaimahi) when exploring tukia (collision) of their personal, professional and cultural worlds.

METHOD: Kaupapa Māori underpinned this research, and pūrākau was utilised to connect the research to Māori worldviews; however, the framework was guided by Pā Harakeke. Pā Harakeke is often used as a metaphor for whānau and a model for protection of children, whānau structure and well-being. Pā Harakeke underpinned the structure of the research and this article will unfurl how it framed the methods and methodology. The harakeke sits well in this research as the focus is on the well-being of kaimahi Māori-caring for the carers, helping the helpers and healing the healers.
\end{abstract}

FINDINGS AND OUTCOMES: An outcome from the Tukia research was that kaimahi shared words of wisdom (Ngā Kupu Taonga) outlining what assisted them to navigate their way through personal-professional collisions. These include self-care, use of appropriate supervision, organisational and cultural support mechanisms and growing from experiences. It is the hope that these taonga may help other kaimahi who experience Tukia in their mahi. These Ngā Kupu Taonga are presented in a Mauri Ora o te Pā Harakeke framework.

KEYWORDS: Harakeke; social work; Kaupapa Māori; kaimahi; tukia

AOTEAROA NEW ZEALAND SOCIAL WORK 32(3), 30-42.

\section{CORRESPONDENCE TO:}

\section{Ange Watson}

A.M.Watson@massey.ac.nz

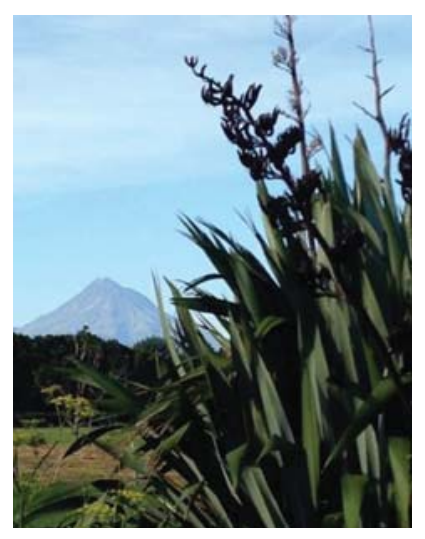

Te Harakeke, Te Kōrari,

Ngā taonga whakarere iho

O te Rangi. O te Whenua. O ngā Tūpuna.

Homai he oranga mō mātou

Tihei Mauri Ora

The flax plant, the flax flower,

Treasures left down here

Of the sky, of the land, of the ancestors,

Give wellness to us all

(http: / / www.flaxwork.co.nz)
(Photograph taken at Kairau Marae, Waitara by the author on 23 February 2017) 
In 2017, I presented the results of research that explored the tukia or collision zones for Māori social workers (kaimahi) when their personal, professional and cultural worlds collided. The research explored tukia and some of the values and ethical issues pertaining to these collision zones (Watson, 2019). This subsequent article will outline and focus on how the Pā Harakeke philosophy underpinned the structure, methodology and methods that were utilised in the Tukia research.

I remember talking with my Head of School as I began my research journey and confiding with him that I was not sure if I would be good at research. He advised me to wait until I was in the process of the research experience because it would start to make more sense once I was doing research. He was right; however, I wondered how I could make the transition to research easier for myself. My own personal framework of social work and supervision practice was grounded in Pā Harakeke and the learnings derived from this. As a social work practitioner, I had utilised the learnings from the Pā Harakeke as a way of working alongside whānau. It was a natural fit because I was able to centre the person (and whānau) I worked alongside as the focus. Then, as a supervisor, I utilised these same learnings, but transplanted them into the supervision arena. This transition was also a natural fit because I was able to place the supervisee as the focus. On my journey to becoming a researcher, I decided to transplant these learnings into my research work where I was able to place the kaimahi (research participant) as the focus. The transitions for myself from social worker to supervisor, and from supervisor to researcher were transformational-however, the secure base of Pā Harakeke aided me immensely through these transition times.

This article will explain Pā Harakeke as a philosophy, and then report on how it provided a practical and pragmatic framework for the Tukia research study by breaking the plant down into nine components, then explaining these components and their relevance and application to the research. As Pā Harakeke sits within a Te Ao Māori framework of Kaupapa Māori, Mātauranga Māori and Pūrākau, this will be explored in terms of the relevance to the research. Finally Ngā Kupu Taonga (words of wisdom) from kaimahi are shared and presented in a Mauri Ora O te Pā Harakeke framework.

\section{Tukia}

The word collision is used in this article to describe the "crashing together of a practitioner's personal, professional and cultural worlds" (Watson, 2017, p. 4). This happens when a social worker's own whānau come into the service they work for, or a service they work closely alongside. There are similarities between the collision zone in social work and the collision zone in rugby because both are "hard-hitting, can be unexpected and can leave you winded, or worst still, wounded and sent off the field with an injury!" (Watson, 2019 , p. 29). The word collision was the most accurate to describe a violent crashing together of the practitioner's worlds causing an impact. The Māori word tukia means to ram and crash into (www.Māoridictionary. co.nz). It can also be used to describe the ramming of a bull's horns (I. Noble, personal communication 25 February 2017) and, in the context of the research, accurately defined the experience of collision as the feeling of being rammed and crashed into.

\section{Pā Harakeke}

Pā Harakeke has often been utilised as a metaphor for whānau and a model of protection for children, and whānau structure and well-being (Metge, 1995; McLean \& Gush, 2011; Pihama, Lee, Te Nana, Greensill, \& Tauroa, 2015; Turia, 2013).

At the centre of the plant is the Rito (1) and represents the baby or child, surrounding the rito are the Awhi rito (2) parent fronds or mātua, then surrounding the awhi rito are the Tūpuna (3) and (4)—-these are the grandparent and ancestor leaves.

(See figure 1: Image of Harakeke) 


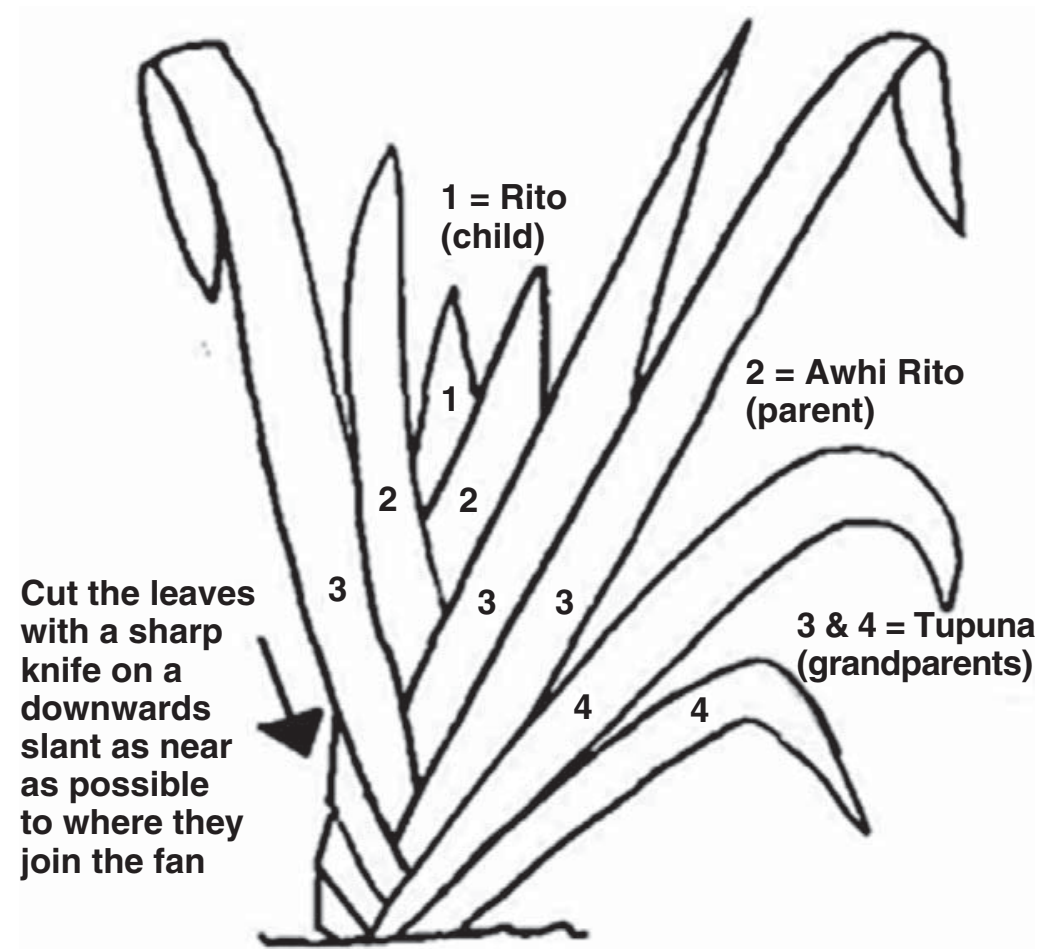

Figure 1. Image of Harakeke (https://my.christchurchcitylibraries.com/harakeke/).

Pā Harakeke as a philosophy is about strengthening the whānau at the centrethe baby (rito) and the parents (awhi rito). The outer fronds (tūpuna) provide protection, shelter and care for the inner fronds. Pā Harakeke is about protection of our most vulnerable, whānau and collective strength, connection to the whenua and to Papatūānuku, our connection to whānau, hapu and iwi, and our connection to the past, the present and the future. Pā Harakeke acknowledges the role and responsibilities of others-the tūpuna (grandparents) in helping to strengthen the whānau-it is about developing community and inter-generational roles and support. It is about whakapapa and protecting whakapapa. It is about regenerating generations. It is about valuing children as a taonga and supporting parents to be the best parents they can by keeping the rito as the focus. It is about growing strong, healthy and flourishing whānau and is a natural fit when working with whānau.

Pā Harakeke descends from a Te Ao Māori framework that allows social workers, supervisors and researchers to utilise knowledge from their Te Ao Māori worldview. Weavers hold a lot of mōhiotanga (understanding) regarding the Pā Harakeke. Tikanga surrounds the Pā Harakeke from before the seed can be planted to the harvesting of the rau (frond leaves). Some tikanga when harvesting the rau includes not cutting the rau when it is raining, nor at night, nor when the kōrari (flower) is in bloom, cutting the rau at a certain downwards angle, and the most important tikanga is Waiho te whānaunever ever cut the whānau in the middle (rito and awhi rito). One only ever takes the tūpuna fronds when harvesting. If you cut the whānau in the middle, the whole Pā Harakeke could die. Karakia are utilised at different times e.g., when planting the harakeke or when harvesting the harakeke.

\section{Pā Harakeke as a research model}

Pā Harakeke can be utilised as a three-fold model: 1) working alongside whānau; 2) in supervision (Eruera, 2005, 2012; Ward, 2006); and 3 ) as a research tool (Isaac-Sharland, 2014; Watson, 2017). A series of writers described the Pā Harakeke as a research model. Eruera $(2005,2012)$ presented He Kōrero Kōrari, a Kaupapa Māori supervision framework, and applied it to different fields of practice and claimed that "Tangata whenua frameworks founded on cultural knowledge, values, principles, beliefs and customary practices contribute to Māori development, self-determination and improved wellbeing for whānau Māori" (2012, p. 13). IsaacSharland (2012) utilised the Pā Harakeke as a metaphoric ideal in her research on the link between Te Reo Māori and Mana Whānau. Whereas Ward (2006) presents the kōrari (Te Tai Tokerau kupu for harakeke) and utilises it as a framework of practice by positioning social work students as the rito, the student's whānau including mentors, class peers and workmates as the awhi rito. Social service lecturers, student services, counsellors and agency supervisors representing hapū are the tūpuna, with Aotearoa New Zealand Association of Social Workers (ANZASW), 
the Social Workers Registration Board (SWRB) and iwi also as tūpuna leaves. The whenua represented the clients who were supported by social work students and practitioners.

Similarly, the intent of the Tukia research was to utilise Pā Harakeke as a research framework by positioning kaimahi as the rito, kaimahi whānau, hapū and iwi and kaimahi organisations (including managers, colleagues, supervisors) as the awhi rito, and the tūpuna fronds representing professional bodies (ANZASW), (SWRB), tertiary education institutions, policies and laws that guide Aotearoa social work practice and the link to global Indigenous social work.

For the purpose of Pā Harakeke as a research model and tool, the plant is comprised of nine components (please see Figure 2. Harakeke framework). These components comprise rito, awhi rito, tūpuna, pakiaka, kōhatu, pakawhā, whenua, kakau, and kōrari. Each of these components will be explained and then the relevance to the research will be highlighted.

\section{Rito-the baby}

Te Rito is the pēpi of the harakeke (the centre shoot) and in the Tukia research, represents the kaimahi who were the research participants. In the research methodology, kaimahi selection and recruitment were discussed, alongside criteria and consents. The criteria for participant selection were that they had to identify as Māori, be a social worker, have over three years' experience in social work, and have experienced a collision of their personal, professional and cultural worlds (defined as when their own whānau are referred to the service they work for or into an organisation that the kaimahi works closely with).

The researcher is an ANZASW Mana Whenua Rōpū member, so there was opportunity to discuss the research at a local hui and pānui were left for prospective participants to make contact. This worked in the kanohi kitea sense of being "the seen



Figure 2. Harakeke Framework (diagram drawn by Hinemoana Watson-Pitcher)

face" and talking to prospective participants' kanohi ki te kanohi (Cram, 2009). The pānui was also sent to ANZASW head office requesting that it be disbursed to Māori social workers in the North Island. There was a great response via ANZASW, in that over 10 responses were received. Seven kaimahi were interviewed for the research, all were ANZASW Māori social workers practising social work in the North Island of Aotearoa, five of them having worked for (in the past or were currently working for) the Department of Child, Youth and Family Services (CYF-now Oranga Tamariki).

By placing the research participantskaimahi-as the rito, they became the focus. One of the reasons I did this relates to me being a supervisor of social workers and the realisation that because social work can be very challenging at times, sometimes the kaimahi need tautoko as much as the whānau they journey alongside do-the helpers need to be helped and the healers need to be healed themselves. Ruwhiu, Ruwhiu, and Ruwhiu (2008) in their article about heart mahi for healers discussed their contribution as a "contribution about caring for healers" (p. 32). Often social workers are not placed in the focal position because the people we work alongside are placed there. 
It is important that the "helpers" are helped and the "healers" are healed because the "wounded healers" (Jung, 1961) can work through their own pain and vulnerability to work effectively with others (Gilbert \& Stickley, 2012) and these kaimahi can contribute significantly to the practice of social work. The Tukia research is about the well-being of the worker and is another way to manaaki and tautoko kaimahi in terms of supporting them through collision experiences. The uniqueness of Pā Harakeke allows kaimahi to be the rito.

\section{Awhi rito-mātua /parent fronds}

The awhi rito are the mātua, the parent fronds of the harakeke. They provide the most immediate shelter and support to the rito. In the Tukia research, the awhi rito represented the kaimahi whānau, hapū and iwi and also included the kaimahi organisational supports i.e., colleagues, managers and supervisors.

Within the discussion chapter of the research, the awhi rito section outlined the supportive and non-supportive systems of whānau and the organisation/mahi where kaimahi work; it also explored the dilemmas kaimahi may face with regard to colluding, considered CYF protocols for working with own family, and discussed the importance of appropriate supervision for Māori social workers.

\section{Tūpuna-grandparent fronds}

The tūpuna fronds are the grandparent fronds that support the awhi rito to support the rito. The tūpuna provide protection, shelter, support and care to the whole whānau unit (rito and awhi rito) of the harakeke. This concept acknowledges the role of tūpuna in helping and supporting whānau and this idea that it takes a village to raise a child.

In the Tukia research, the tūpuna is represented by kaimahi professional bodies (SWRB and ANZASW), tertiary education institutions where kaimahi trained (the influence of their social work training), and the policies and laws that guide Aotearoa social work practice. Tūpuna also links to global Indigenous social work. In the discussion chapter of the Tukia research there was a focus on the policies and laws that guide social work practice historically and currently in Aotearoa, particularly Pūao-te-Ata-tū (1988), the Children, Young Persons and their Families Act 1989, and the United Nations Declaration of the Rights of Indigenous Peoples' (2007) outcome of changes, and how this links globally to indigenous social work. It also explored the Children, Young Persons, and their Families (Oranga Tamariki) Legislation Bill (New Zealand Legislation, 2017) introduced into Parliament in midDecember 2016. These proposed changes were part of the transformation of CYF to the new Ministry for Vulnerable Children (Oranga Tamariki) which became a standalone Ministry with a separate Chief Executive.

\section{Pakiaka-roots}

The pakiaka are the roots of the harakeke which are hidden within the whenua and Papatūānuku and are not normally seen by the naked eye.

The pakiaka represent the foundation and the underpinnings of the Tukia research. These encompass a Te Ao Māori view of the world underpinned by te reo Māori and tikanga. A Kaupapa Māori approach was undertaken for the Tukia research, alongside pūrākau pedagogy. Pakiaka also houses the kaimahi personal worldviews, values, beliefs and ethics. This is because these are our foundational beliefs and views of the world that ground us and give us roots. Kaupapa Māori theory and pūrākau pedagogy outlined and discussed the story of Te Wehenga-the separation of the primal parents Ranginui and Papatūānuku by their sons-and this was utilised to demonstrate the whakapapa of the universe, of mankind and the Pā Harakeke. 


\section{Kaupapa Māori}

Kaupapa Māori is primordial; having existed from age-old times, and is evident in Māori whakapapa back to Io-Matua-teKore (the Creator of Te Kore) (Pihama \& Southey, 2015). Pihama explains, "Kaupapa Māori is extremely old - ancient, in fact. It predates any and all of us in living years and is embedded in our cultural being" (2015, p. 9). The foundation work of Kaupapa Māori theory was executed by Graham Smith (1997) and Linda Tuhiwai Smith (1999) in the field of education. G. H. Smith (1997) espouses that Kaupapa Māori is an evolving, transformative theory that can be understood through initiatives spearheaded by Māori, which connect to being Māori and link to Māori philosophy and principles. He highlighted six key principles of Kaupapa Māori: Tino Rangatiratanga (Selfdetermination principle), Taonga Tuku Iho (Principle of cultural aspiration), Ako Māori (Principle of culturally preferred pedagogy), Kia Piki Ake I Ngā Raruraru o te Kāinga (Principle of socio-economic mediation), Whānau (principle of extended family structure), and Kaupapa (principle of collective philosophy) (Cram, 2012). Walker (1996) described Kaupapa Māori theory as a theoretical framework that is fluid and evolving, and as an Indigenous theory of change that is transformative. L.T. Smith (1999) sees Kaupapa Māori as decolonising theory and asserts that outsider research on Māori has impacted negatively and left Māori distrustful of research. This affirms that outsider research has continued to colonise Māori, and Kaupapa Māori should be, "theory and practice of active resistance to the continued colonisation of Māori people and culture" (Mahuika, as cited in Pihama \& Southey, 2015, p. 43). Pihama upholds that Kaupapa Māori, "must be about challenging injustice, revealing inequalities, and seeking transformation" (2001, p. 110). Kaupapa Māori values Maori knowledge and ways of doing, focusses on emancipatory research by Māori, with Māori, for Māori, and empowers whānau, hapū and iwi (Moyle, 2013; Pihama \& Southey, 2015; L.T.Smith, 1999). In this sense, Kaupapa Māori research is seen as an emancipatory, decolonising, transformative process whereby Māori researchers are "insider researchers," walking alongside their Māori participants on a journey of tino rangatiratanga for the betterment of iwi Māori. This is firmly set in Mātauranga Māori.

Mātauranga Māori has been defined as Māori knowledge (Pihama, Smith, Taki, \& Lee, 2004) and in Māori Pūrākau, mātauranga was a gift from Io-Matua-teKore and brought to the earthly realm when Tāne ascended the heavens and brought back the three kete of knowledge (RikihanaHyland, 1997). Royal (1998) ascertains that whakapapa is a vehicle for, and an expression of, Mātauranga Māori and that the whakapapa origins of Mātauranga Māori take us back to Papatūānuku and Ranginui. Mātauranga Māori is an important component of Kaupapa Māori research, as is Te reo Māori and tikanga (L.T. Smith, 1999).

Māori research requires the researcher to assert their identity and understand that colonisation has made it a "damaged identity ... but it was also a resilient and resistant identity" (Tuhiwai-Smith, 2013, p. 2). Māori research is also about asserting tino rangatiratanga and understanding the framework of Te Tīriti o Waitangi and how it might be lived out if it was fully honoured. A key component of a Kaupapa Mãori philosophy is the assertion of the strength and resilience of Māori voices, experiences and conditions (L.T. Smith, 2005). Therefore, Kaupapa Māori is a vehicle for transformation for Māori researchers and is testament to the resistant and resilient capacity of Māori.

\section{Kaupapa Māori approach in the Tukia Research}

I have been a social work practitioner grounded in practice; my strength was in social work practice. I have always been more interested in the practical application of practice to real life so the foundation 
of this research comes from Kaupapa Māori approaches that I have utilised in my practice- the Pā Harakeke model and Pūrākau. Pā Harakeke and Pūrākau grounded this research in a Māori worldview (Taonga Tuku Iho principle). Kaupapa Māori approach in this research acknowledges that I am a Māori researcher who identifies as Māori thereby having "insider status." I carried out Māori research with Māori practitioners (Tino Rangatiratanga principle); therefore, this research sits within a Maori worldview (Principle of Ako Māori). This research valued Mãori ways of knowing and doing, and aspired to positive outcomes and aspirations for kaimahi, whānau, hapū and iwi (Kaupapa principle).

Cheryl Waerea-i-te-rangi Smith identifies Kaupapa Māori theory as emerging, "out of practice, out of struggle, out of experience of Māori who engage struggle, who reject, who fight back, and who claim space for the legitimacy of Māori knowledge" (2002, p. 13). This aligns to the Tukia research because it takes the journey of kaimahi who may have engaged in struggle through collision experiences, to legitimately claim space through Māori knowledge. A Kaupapa Māori approach allowed for a tino rangatiratanga journey of the kaimahi Māori participating in the research, as well as myself as the Māori researcher. Kaupapa Māori is utilised in all aspects of the methodology i.e., collecting data, analysing data, engaging with participants, and working with supervisors as this is part of tino rangatiratanga and collective understanding.

\section{Kōhatu-pebbles/stones for drainage}

The kōhatu are the pebbles/stones that allow for drainage surrounding the roots below the harakeke. Kōhatu represent the ethics and boundary issues of the research. The reasoning for this is that the kohatu physically sit within the pakiaka (roots) of the harakeke and the pakiaka is where the values, beliefs and worldviews of kaimahi sit. Ethics and boundary issues sit within and are impacted by our worldviews, values and beliefs. In the Tukia research methodology, Māori cultural ethical principles that guide Kaupapa Māori research were encompassed in this section, as well as discussion regarding the Massey University Human Ethics Process, and discussion of any conflicts of interest.

\section{Ethical considerations}

Mead outlines seven Māori cultural ethical principles that guide Kaupapa Māori research (1996, p. 221) and other Māori researchers have outlined these principles as well (Bishop, 1996; Cram, 2009; L.T.Smith, 1999). The principles are outlined as: Aroha ki te tangata (love and respect for people), He kanohi kitea (the seen face), Titiro, whakarongo ... kōrero (look, listen and then speak), Manaaki ki te tangata, Kia tūpato (be cautious), Kaua e takahia te mana o te tangata (do not trample on the mana of people), and Kia māhaki (be humble). These principles were the guide for the ethical considerations of the Tukia research and were unpacked in the Kōhatu section further.

The Tukia research identified several challenges, ethical dilemmas and boundary issues by kaimahi experiencing collision. These were pinpointed to accountability issues, conflicting cultural tensions, issues of biculturalism in practice, and the issue of colluding (Watson, 2019, p. 31). These were the kōhatu of the Pā Harakeke model.

\section{Pakawhā-old, withered fronds of experience}

The pakawhā are the old, withered fronds, near the base of the harakeke, that start to change colour and drop off the harakeke plant back to the whenua, the earth. The pakawhā represent the experiences of kaimahi-both positive and negative. The positive experiences are incorporated into kaimahi practice and the negative experiences are released back to Papatūānuku (as they fall off the harakeke) 
thus helping to regenerate the plant. From a resilience and strengths perspective, the negative experiences are seen as a learning opportunity and can still contribute to the well-being of the Pā Harakeke-thus there is learning from all experiences.

Within the Tukia research, kaimahi shared their positive and negative experiences of collision and how they were helpful or unhelpful for them.

\section{Whenua-the land}

Mā te tū i runga i te whenua ka rongo, Mā te rongo ka mōhio, Mā te mohio ka marama, Mā te mārama ka mātau, Mā te mātau ka ora!

By standing on the land you will feel, in feeling you will know, in knowing you will understand, in understanding comes wisdom and then life!

This whakataukī illustrates the fundamental importance of whenua to Māori. The whenua is our link to Papatūānuku and the land where the Pā Harakeke nestles. Papatūānuku, the great earth mother, the "rock foundation beyond expanse, the infinite" (Marsden, as cited in King, 1992, p. 135) elevates the female role for Māori and forms the basis of mana wāhine relationships and all relationships. Murray (2012) discusses the importance for Māori of reconnecting to Papatūānuku by returning to the whenua and that "the relationship we have with Papatūānuku is reflected in the relationships we have with ourselves and others" (p. 10). The whenua is our connection to Papatūānuku and our whakapapa to our Creation story in Te Ao Māori. In the Tukia research, the whenua is explored further through the use of pūrākau as pedagogy. Papatūannuku is the base, the framework, the solid, secure attachment that I go to in times of need and Papatūānuku is the solid, secure framework that is a Kaupapa Māori way of doing. Pihama et al. (2004) stated that a Kaupapa Māori theoretical foundation has to be constructed from Papatūānuku. Our creation story and narratives form the basis of our worldviews and ways of doing in Te Ao Māori.

\section{Kakau-the strong stalk}

The kakau is the strong stalk of the harakeke that will eventually hold the kōrari-the flower.

In the Tukia research methodology, the kakau represented the methods used within the research. The kakau unpacked the data collection, personal interviews, the interview process, whānau tautoko, respect for privacy and confidentiality, the collection and storage of data, data analysis, participant rights, researcher responsibilities, and equipment.

All interviews were kanohi ki te kanohi and occurred throughout the North Island, from Wellington to Auckland. Interviews were audio-recorded and later transcribed by the researcher. Transcripts were returned to kaimahi for checking, approval and consent. Kaupapa Māori research methods used in the interview process included karakia, whakataukī, waiata, whakawhanaungatanga and whakapapa connection, use of conversational te reo Māori, koha (in the form of gift cards) and the provision of kai as part of manaakitanga.

Personal interviews were utilised in the research because they are a qualitative method of inquiry and aligned well with Kaupapa Mãori research, particularly in being kanohi ki te kanohi with kaimahi. Interviews are an effective method in assisting understanding of the lived experience of participants (Patton, 2002) and the research was about capturing the lived experiences of kaimahi who had experienced collision.

In the Tukia research, the Pā Harakeke was often utilised as a framework to structure the research into order. In the Methodology and Methods section, the framework incorporated the following four themes: 1. Pakiaka/ roots (Kaupapa Māori theory 
and approach); 2. Rito/child (Kaimahi/ Participants); 3. Kakau/stalk (Methods); and 4. Kōhatu/pebbles for drainage (Māori Ethical Considerations) and these sections were explored in detail. The data were analysed into six key themes with subthemes. These themes originated from the interview questions: 1 ) managing the collision (what helped, hindered and could have helped); 2) impact of the collision (personal, professional, cultural); 3) influences on managing the collision (values and beliefs, worldviews); 4) Dual Roles, Accountabilities, Boundary Issues and Ethical Dilemmas; 5) Words of Wisdom; and 6) Emerging Themes (Differences in ways of working, conflicting cultural tensions, and working biculturally). The sixth theme had not been a direct focus of the research questions interview schedule but had emerged from the interviews. Then in the Discussion section these six key themes were categorised into the Pā Harakeke framework again as: 1) Te Rito: Kaimahi, 2) Pakiaka: Māori worldview; 3) Awhi Rito: awhi/tautoko from whānau, organisations and supervisors; 4) Kōhatu: Ethics, boundaries, dual roles and accountabilities, conflicting cultural tensions; 5) Tupuna: Laws and policies guiding social work and links to Indigenous social work globally; and 6) Kōrari: Words of wisdom. Within the Tukia research there were many opportunities to utilise the Pā Harakeke model as a framework.

\section{Kōrari-the flower}

The kōrari is the flower of the harakeke and ngā manu (komakō and tui) come to feed off the kōrari. The kōrari is the pinnacle of the Tukia research as it represents the outcomes and learnings from the research. A tangible outcome of the kōrari is represented in the Mauri Ora O te Pā Harakeke: Ngā kupu taonga (see Figure 3).

Ngā kupu taonga were words of wisdom shared by kaimahi who have experienced personal-professional collisions. The taonga are represented by the different components of the Pā Harakeke.

\section{Te Taonga o te Rito}

These are the learnings and taonga from the rito or kaimahi themselves and included: a) Care of Self- "Be gentle on your 'self"'. Kaimahi shared that, when going through the tukia experience they needed to be gentle on themselves, look after themselves and do what made them feel well. They also shared that it was important to have confidence in yourself and have self-compassion;
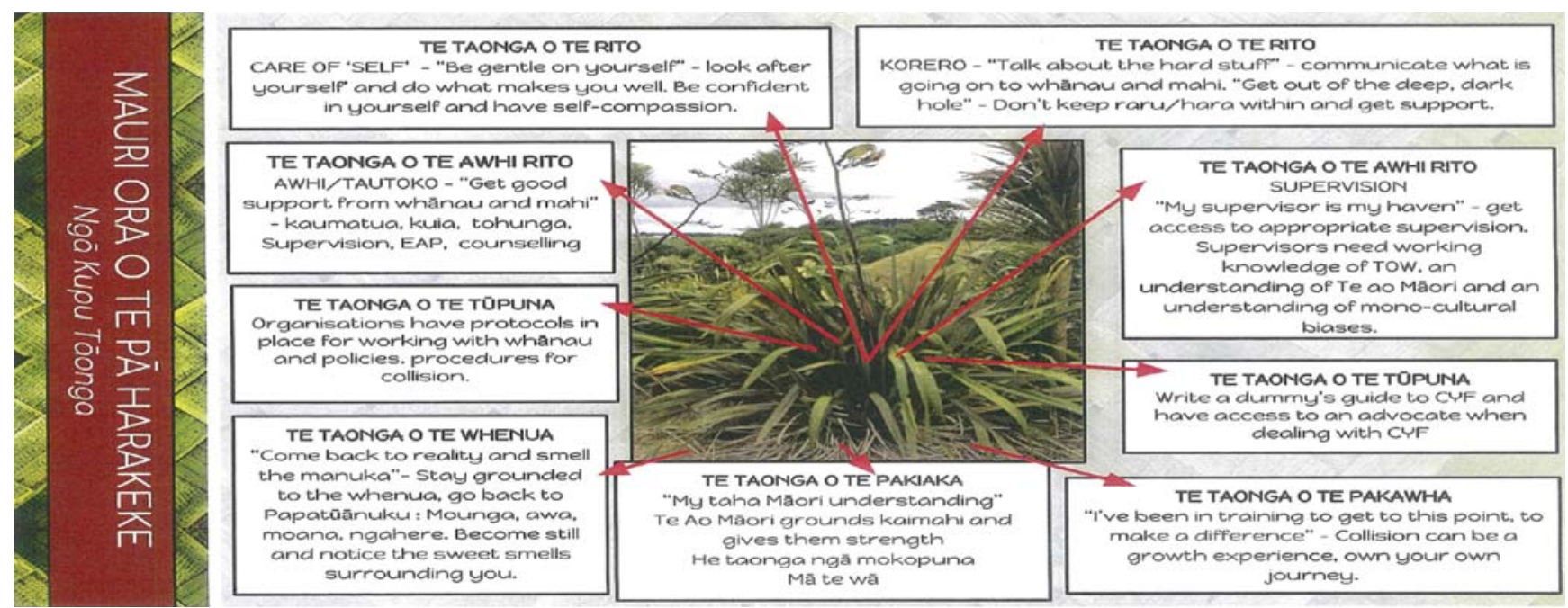
hole" - Don't keep raru/hara within and get support.

Figure 3. Mauri Ora O te Pā Harakeke: Ngā Kupu Taonga. 
b) Kōrero- "Talk about the hard stuff". Kaimahi disclosed that being able to "talk about the hard stuff" was essential and becoming a good communicator was necessary. Kaimahi needed to communicate what was going on for them during the tukia experience by talking with whānau members and work colleagues; c) "Get out of the deep, dark hole." This taonga is about not keeping the raru within and sharing the burden. Talk about what is going on-go through the process of it, acknowledge it and embrace vulnerability. Again communication is essential. Kaimahi expressed that they needed to be proactive in getting support for themselves.

\section{Te Taonga o te Awhi Rito}

The learnings from the awhi rito (kaimahi whānau, hapū and iwi, as well as kaimahi organisations including colleagues, managers and supervisors) included: a) Awhi / Tautoko-_Get good support from whānau and mahi." Kaimahi shared that it was essential to get good support from whānau and work colleagues and to utilise kaumātua and kuia support and, if necessary, tohunga support. From their organisational side, kaimahi discussed the supports of supervision, Employee Assistance Programme (EAP), and counselling as being helpful to manage the collision experience; and b) Supervision"My Supervisor is my haven." The role of appropriate and supportive supervision was highlighted by kaimahi as being essential to manage their way through the tukia experience. The "My supervision is my haven" comment by one kaimahi showed the need to access appropriate supervision for kaimahi Māori. Supervisors need a good working knowledge of Te Tiriti o Waitangi, an understanding of Te Ao Māori and an understanding of mono-cultural biases and how these impact on the supervision forum (Elkington, 2014; Eruera, 2012; King, 2014; Lipsham, 2012; Murray, 2012).

\section{Te Taonga o te Tūpuna}

These are the learnings from the tūpuna (grandparent fronds which encompass professional bodies i.e., SWRB and ANZASW, the tertiary education institutions where kaimahi trained, policies and laws that guide Aotearoa social work practice and the link to global Indigenous social work): a) Organisational protocols for collisionorganisations should have clear protocols in place for working with whānau, and policies and procedures for dealing with collision issues for kaimahi, supervisors and managers in navigating when whānau are coming through their services. Kaimahi stated that it was better to have something in place rather than muddle their way through as a collision unfolded for the kaimahi and their organisation; and b) a Dummy's Guide to CYF (now Oranga Tamariki). It was suggested by kaimahi that it would be helpful if there was a Dummy's guide to CYF to help whānau navigate their way through the organisational processes when dealing with CYF. It was also suggested that whānau should have access to an independent advocate when dealing with CYF.

\section{Te Taonga o te Whenua}

These are the learnings from the whenua (our connection to Papatūānuku). The first taonga was Ground yourself- “ Come back to reality and smell the manuka." The whenua is the ground on which the harakeke nestles and the whenua taonga is to stay grounded and come back to Papatūānuku by going to maunga, awa, whenua, moana, roto and ngāhere. This involves seeing, hearing, touching, smelling and tasting. This saying talks about the kaimahi having clear expectations and understanding of expectations and idealism i.e., what the kaimahi wants to do and what they can realistically do. This is about remaining grounded and realistic and keeping our feet on the ground as we are seeds and descendants of Papatūānuku. Grounding themselves assisted kaimahi through the Tukia experience.

\section{Te Taonga o te Pakiaka}

These are the learnings from the pakiaka (the roots, particularly represents kaimahi 
worldview, values, beliefs and ethics). The pakiaka are the roots and represent the Māori worldview and understanding of the kaimahi, underpinned by tikanga Māori and concepts. Te Ao Māori grounded kaimahi and gave them strength, "My taha Māori understanding that I have a belief that life continues, there is no end, and that everything happens for a reason." Kaimahi particularly viewed mokopuna as taonga, reinforced the idea of "Mā te wā", and were aligned to the philosophy of te tino rangatiratanga.

\section{Te Taonga o te Pakawhā}

These are the taonga from the Pakawhā (the old withered fronds that represent the experiences of kaimahi-both positive and negative). "I've been in training to get to this point, to make a difference!" Kaimahi expressed that, although collision can be confronting and challenging, it can also be a growth experience that makes them stronger and more resilient, and better equipped to work alongside other whānau experiencing challenges. The taonga here is that collision can be a growth experience, that kaimahi will come out the other side of and it is important to own your own journey.

Ngā kupu taonga were shared openly by kaimahi and give good direction to others that may be experiencing collisions of their worlds. They also indicate that there is a pathway through collisions and that kaimahi will come out the other side; however, it is important to ensure there are robust processes and supports to help kaimahi through and there is an emphasis on the importance that kaimahi kōrero about what is going on. One of the key messages is that collision can be a growth experience that kaimahi will come out the other side from and there is a strong possibility that it will become a lived experience that will strengthen kaimahi practice.

As mentioned earlier, the kōrari is the flower that will be fed upon by ngā manu. The tui and kōmako are often found on the kōrari. Ngā manu will represent the people who will be interested in and feed from this research-students, lecturers, kaimahi, organisations, whānau, hapū and iwi.

\section{Conclusion}

Utilising Pā Harakeke as a framework for this research, the kaimahi were placed as the rito. In this instance the kaimahi is the rito/baby that needs protection, nurture and safety. The rito are the seven kaimahi who were interviewed for the Tukia research. The awhi rito / parent plants that support the rito were the kaimahi whānau, hapū and iwi and also the organisation/ agency they worked for including managers, team leaders, supervisors and colleagues. It is the mahi of the awhi rito to protect, nurture and keep the rito safe. The tupuna/grandparent fronds are represented by the professional bodies of ANZASW and SWRB, and the tertiary education institutions (where kaimahi have acquired social work training from). Also included in the tūpuna fronds are the policies and laws that guide Aotearoa social work and the link to indigenous social work globally. The tupuna fronds support the awhi rito to enable them to continue to support the kaimahi as the rito. The pakiaka are the roots of the harakeke and these roots go down deep under the harakeke and represent the underpinnings of the research. Pakiaka represents the Māori worldview and understanding of the kaimahi, underpinned by tikanga Māori and concepts, and kaimahi values and beliefs, as well as the Kaupapa Māori approach to this research. The kōhatu are the stones / pebbles that allow drainage for the harakeke and surround the pakiaka. The kōhatu are the ethics / boundaries, dual roles and accountabilities, and the conflicting cultural tensions experienced by kaimahi, and also the ethical considerations of the research. The pakawh $\bar{a}$ are the old, withered fronds found near the base of the plant. These fronds represent the experiences of the kaimahiboth positive and negative. The positive 
experiences are incorporated into kaimahi practice and the negative experiences are released back to Papatūānuku (as they fall off the harakeke) thus helping to regenerate the plant. From a resilience and strengths perspective, the negative experiences are seen as a learning opportunity and can still contribute to the well-being of the Pā Harakeke thus there is learning from all experiences. The kakau is the stalk that will eventually hold the flower or kōrari on the harakeke and represents the methods used in this research-including the research design, the sample, participant recruitment, the interview process, the storage and collection of data, and the analysis of the data. All of these methods will lead to the findings and analysis which are represented by the kōrari. The kōrari is the flower of the harakeke and represents the outcomes and learnings from the research and ngā kupu taonga that kaimahi will pass on to others experiencing collision. The pinnacle of the research is found here in the kōrari-the flower that will be fed upon by ngā manu. Ngā manu are the birds that will feed off the korrari; the tui and kōmako are often found on the kōrari and ngā manu represent the people who are interested in the Tukia research results.

This article has outlined the methodology and methods used in the Tukia research study. Kaupapa Māori theory underpinned the research, pūrākau pedagogy informed the research methodology, and the Pā Harakeke model underpins the layout and structure of this research. This approach allowed the Māori researcher to have insider status, to carry out Māori research with Māori practitioners, a by Māori, with Māori, for Māori approach that allowed for a tino rangatiratanga journey for the kaimahi participating in the research, as well as the researcher. This research also values Māori ways of knowing and doing, and aspires to positive outcomes and aspirations for kaimahi, whānau, hapū and iwi through the journey of kaimahi who may have engaged in struggle through personal-professional collision experiences.

Also highlighted is the Mauri Ora O te Pā Harakeke: Ngā kupu taonga which kaimahi have shared as words of wisdom for other kaimahi who might be experiencing collision of their personal and professional worlds. Kaimahi expressed that, although collision can be confronting and challenging, it can also be a growth experience that can make them stronger and more resilient, and better able to work alongside other whānau experiencing challenges.

Mā te hē, ka tika.

Learning is achieved through experience.

Accepted 1 September 2020

Published 3 November 2020

\section{References}

Bishop, R. (1996). Addressing issues of self-determination and legitimation in Kaupapa Māori research. In He Paepae Kō rero: Research perspectives in Māori education (pp. 142-160). Wellington, NZ: New Zealand Council for Educational Research.

Cram, F. (2009). Maintaining indigenous voices. The handbook of social research ethics. Sage.

Elkington, J. (2014). A Kaupapa Māori supervision context cultural and professional. Aotearoa New Zealand Social Work Review, 26(1), 65-73.

Eruera, M. (2005). He Kōrero Kōrari: Supervision for Māori. Weaving the past, into the present for the future (Master's thesis). Massey University, Palmerston North.

Eruera, M. (2012). He Kōrari, he kete, he kōrero. Aotearoa New Zealand Social Work Review, 24(3\&4), 12-19.

Gilbert, P., \& Stickley, T. (2012). Wounded healers: The role of the lived experience in mental health education and practice. The Journal of Mental Health Training, Education \& Practice, 7(1), 33-41.

Harakeke image. (n.d.). Christchurch City Libraries. Retrieved from https://my.christchurchcitylibraries.com/harakeke/

Isaac-Sharland, W. (2014). Ora ai te mana o te whānau İna kōrero Māori?: What is the link between te reo Māori and mana whānau or whānau empowerment? (Master's thesis). Massey University: Palmerston North, NZ.

Jung, C. (1961). Memories, dreams and reflections. Fontana Press.

King, L. (2014). KIAORA - The emerging construction of a bicultural professional supervision model. Aotearoa New Zealand Social Work Review, 26(1), 20-28.

King, M. (Ed.). (1992). Te Ao Hurihuri: Aspects of Māoritanga. Octopus Publishing. 
Lipsham, M. (2012). Āta as an innovative method and practice tool in supervision. Aotearoa New Zealand Social Work Review, 24(3\&4), 31-40.

McLean, M., \& Gush, P. (2011). Submission from Regiona Public Health, Wellington to Māori Affairs Select Committee Inquiry into the Determinants of Wellbeing for Māori Children. Retrieved from https://www. parliament.nz/en/pb/sc/submissions-and-advice/ document/50SCMA_EVI_00DBSCH_INQ_11080_1_ A216743/regional-public-health-hutt-valley-districthealth-board

Mahuika, R. (2015). Kaupapa Māori theory is critical and anticolonial. In L. Pihama \& K. Southey (Eds.), Rangahau: A reader. A collection of readings from the Kaupapa Māori research workshops series (pp.34-36). University of Waikato.

Marsden, M. (1992). God, man and universe: A Māori world view. In M. King (Ed.), Te Ao Hurihuri: Aspects of Māoritanga. Octopus Publishing Group.

Mead, L. T. R. (1996). Ngā aho o te kākahu mātauranga: The multiple layers of struggle by Māori in education (Unpublished doctoral dissertation). University of Auckland, Auckland, NZ

Metge, J. (1995). New growth from old: The whānau in the modern world. Victoria University Press.

Moyle, P. (2013). From family group conferencing to whānau ora: Māori social workerstalk about their experiences (Master's thesis). Massey University, New Zealand.

Murray, V. (2012). Hoki ki tōu maunga kia purea ai e koe ki ngā hau o Tāwhirimātea - A supervision model. Aotearoa New Zealand Social Work Review, 24(3\&4), 3-11.

New Zealand Legislation. (2017). Children, Young Persons, and their Families (OrangaTamariki) Legislation Bill. Retrieved from http://www.legislation.govt.nz/bill/ government/2016/0224/latest/d56e2.html?search=qs_ac t\%40bill\%40regulation\%40deemedreg_Children\%2c+Y oung+Persons+and+Their+Families+(Oranga+Tamari ki)_resel_25_h\&p=1\&sr=1

Patton, M. (2002). Qualitative research and evaluation methods (3rd ed.). Sage.

Pihama, L. (2001). Tihei Mauri ora: Honouring our voices. Mana wahine as a Kaupapa Māori theoretical framework (Unpublished doctoral thesis). University of Auckland, NZ.

Pīhama, L., Lee, J., Te Nana, D. C., Greensill, H., \& Tauroa, T. (2015). Te pā harakeke: Whānau as a Site of Wellbeing In R. Rinehart, E. Emerald \& R. Matamua (Eds.), Ethnographies in Pan Pacific research: Tensions and positionings (pp. 251-266). Routledge.

Pihama, L., Smith, K., Taki, M., \& Lee, J. (2004). A literature review on kaupapa Māori and Māori education pedagogy. The International Research Institute for Māori and Indigenous Education.

Pihama, L. \& Southey, K. (Eds.). (2015). Kaupapa Rangahau: A reader. A collection of readings from the Kaupapa Māori research workshops series. Te Kotahi Research Institute.

Rikihana-Hyland, Q. (1997). Paki Waitara: Myths and legends of the Māori. Reed Publishing (NZ).
Royal, C. (1998). Mātauranga Māori: Paradigms and politics. A paper presented to the Ministry for Research, Science and Technology, 13. Retrieved from http://www. mcguinnessinstitute.org/wp-content/uploads/2016/10/ Politics-and-Paradigms-Charles-Royal.pdf

Ruwhiu, P., Ruwhiu, L.A., Ruwhiu, L. L. (2008). To Tātou Kupenga: Mana tangata supervision: A journey of emancipation through heart mahi for healers. Te Komako, 4, 13-34.

Smith, C. W. (2002). He pou herenga ki te nui: Māori knowledge and the university (Unpublished doctoral thesis). The University of Auckland, Auckland, New Zealand.

Smith, G. H. (1997). The development of Kaupapa Māori theory and praxis (Unpublished doctoral thesis). University of Auckland, NZ.

Smith L. T. (1999). Decolonizing methodologies: Research and indigenous peoples, London: Zed Books.

Smith, L. T. (2005). On tricky ground: Researching the native in the age of uncertainty. In N.K. Denzin \& Y. S. Lincoln (Eds.), The Sage handbook of qualitative research (3rd Ed). Thousand Oaks, CA: Sage.

Smith, L. T. (2013). Live up to our talk. Keynote address from He Manawa Whenua Conference 2013. Published on 1 December 2015.

Retrieved from https://indigenousknowledgenetwork. net/2016/07/07/linda-tuhiwai-smith-live-up-to-our-talk/

Te Harakeke, Te Kōrari Karakia. (n.d.). Retrieved from http://www.flaxwork.co.nz

Turia, T. (2013, 11 November). Fostering te Pā Harakeke. Healthy and prosperous families of mana. Speech on Whānau Ora. Retrieved from https://www.beehive. govt.nz/speech/fostering-te-pa-harakeke-healthy-andprosperous-families-mana

United Nations. (2007). United Nations Declaration on the Rights of Indigenous Peoples. Retrieved from https:// www.un.org/development/desa/indigenouspeoples/ declaration-on-the-rights-of-indigenous-peoples.html.

Walker, S. (1996). Kia tau te rangimarie: Kaupapa Māori theory as a resistance against the construction of Māor as the "Other" (Unpublished Master's thesis). University of Auckland, Auckland.

Ward, P. (2006). Tuia te whakairo kia tina - Working together, learning to understand each other, enhancing our well-being. Social Work Review, 18(4) 70-77.

Watson, A. (2017). Tukia: Ma te hē, ka tika. Māori social workers' experiences of the collision of their personal, professional and cultural worlds (Master's thesis). Massey University, Palmerston North, New Zealand.

Watson, A. (2019). Collision: An opportunity for growth? Māori social workers' collision of their personal, professional, and cultural worlds and the values and ethical challenges within this experience. Journal of Social Work Values and Ethics, Fall, 16(2), 28-39.

www.Māoridictionary.co.nz. (n.d.). Definition of tukia. Retrieved from http://Māoridictionary.co.nz/search?idio $\mathrm{m}=$ \&phrase=\&proverb=\&loan=\&histLoanWords=\&keyw ords=tukia 